LUTSENKO V. A. ${ }^{1}$, POLISHCHUK L. V. ${ }^{1}$, HONG J. ${ }^{2}$, FOMINA M. A. ${ }^{1 凶}$

${ }^{1}$ D.K. Zabolotny Institute of Microbiology and Virology of NAS of Ukraine, Ukraine,03143, Kyiv, Acad.Zabolotnoho str., 154, e-mail: M.Fomina@ukr.net

${ }^{2}$ Marine Biodiversity Institute of Korea,

Korea, 33662, Chungcheongnam-do

$\bowtie$ M.Fomina@ukr.net

\title{
XEROTOLERANT STRAIN OF PENICILLIUM CHRYSOGENUM MF18_10 ISOLATED FROM THE DAMAGED WALLS OF SAINT SOPHIA'S CATHEDRAL, KYIV
}

\begin{abstract}
Aim. The aim of this work is to determine the taxonomic position of the fungal strain MF18_10 isolated from the damaged wall with medieval painting of St. Sophia's Cathedral (Kyiv, Ukraine). Methods. The fungus was isolated on selective medium for xerophilic fungi $(70 \%$ sucrose Czapek agar). Macro- and micro-morphological phenotypic characterization was carried out using light and scanning electron microscopy. Molecularbiological identification was performed using nucleotide sequences of the ITS-fragment. Results. On the basis of phenotypical characteristics of the fungal isolate MF18_10, it was established its affiliation to the genus Penicillium. ITS analysis revealed that the isolate belongs to the species P. chrysogenum demonstrating $100 \%$ identity with other 78 P. chrysogenum strains in GenBank database including the type strains NR_077145 and AY373902, also sharing several distinct differences in substitutions, deletions and insertions within this group. Conclusions. The isolated xerotolerant fungus was identified as $P$. chrysogenum, the typical representative of the indoor environments and dust, and also common for mycobiota of damaged historic-cultural artifacts. The differences in the analyzed $P$. chrysogenum ITS primary structures did not correlate with the source of isolation.
\end{abstract}

Keywords: Penicillium chrysogenum, xerotolerant fungi, ITS, scanning electron microscopy.

Nowadays, the problem of the deterioration of cultural and historical monuments by microorganisms is becoming more and more relevant. Many historically valuable buildings all over the world undergo biodegradation, especially through microscopic fungi - micromycetes. Recently, the dark-stained deterioration has been discovered in some parts of the unique medieval murals of Saint Sophia's Cathedral in Kyiv, Ukraine, which could be caused by micromycetes. The knowledge of the nature of deterioration and the microorganisms involved is essential for fighting microbial invasion and saving cultural and historical heritage [1-5].

Among the areas of the ribosomal cistron, the region of the internal transcribed spacer (ITS) has the highest probability of successful identification for a wide range of fungi, with the most clearly distinguished barcode gap between interspecific and intraspecific variations, and therefore ITS was proposed as a standard barcode for fungi. ITS region combines the highest resolution to distinguish similar species with the high PCR and sequencing success in a wide range of fungi [6].

This work was aimed at the phenotypic and ITS-based molecular-biological identification of the culturable fungus isolated by us from the deteriorated walls with medieval painting in St. Sophia's Cathedral (Kyiv, Ukraine).

\section{Materials and methods}

The culture of the microscopic fungus MF18_10 was isolated in 2018 from the darkstained deterioration on the walls of St Michael Altar in St. Sophia's Cathedral in Kyiv, Ukraine. Considering the interior conditions in the Cathedral, the selective medium for xerophilic fungi $70 \%$ sucrose Czapek agar (CZA70S) was used for isolation. The phenotypic characteristics of colonies were also observed on malt extract agar supplemented with $10 \% \mathrm{NaCl}(\mathrm{MEA}+10 \% \mathrm{NaCl})$, Czapek yeast extract agar supplemented with $20 \%$ sucrose (CY20S), malt yeast extract agar supplemented with $40 \%$ sucrose (MY40S), potato dextrose agar supplemented with $15 \% \mathrm{NaCl}(\mathrm{PDA}+15 \% \mathrm{NaCl})$, and malt extract agar (MEA). The isolate was incubated for 14 days at $25^{\circ} \mathrm{C}$ in darkness [1, 4, 7-9]. Light microscopy of the mycelium was performed using Primo Star Zeizz light microscope equipped with a Canon PowerShot A640 camera. Tescan Mi-

\footnotetext{
${ }^{\circ}$ LUTSENKO V. A., POLISHCHUK L. V., HONG J., FOMINA M. A.
} 
ra 3 LMU microscope was used for scanning electron microscopy (SEM).

In order to detail the taxonomic position of the fungal culture MF18_10, we analyzed the nucleotide sequence of the isolate's ITS-fragment containing the 5'-end of the 18S rRNA gene, ITS1, 5.8S rRNA gene, ITS2, the 3'-end of the 26S rRNA gene [10-12]. Universal fungi primers ITS1 5'TCCGTAGGTGAACCTGCGG-3' and ITS4 5'TCCTCCGCTTATTGATATGC-3' were used to amplify the ITS chromosome fragment [10]. The nucleotide sequence of the ITS of the isolate MF18_10 (585 bp) was placed in GenBank under the accession number MK367422 and its primary structure was used in our study as a reference sequence [10-12].

\section{Results and discussion}

The phenotypical features of the fungal isolate MF18_10 demonstrated its affiliation to the genus Penicillium (family Aspergillaceae, order Eurotiales, phylum Ascomycota) (Fig. 1A). It was shown that the isolate formed distinctive for the genus dense brush-like spores-bearing structures conidiophores terminated by the clusters of flaskshaped phialides (length around 6-9 $\mu \mathrm{m}$ ) with the chains of smooth conidiospores (size 2-4 $\mu \mathrm{m}$ ). Phialides were supported by secondary branches of a conidiophore metulae (length around 6-9 $\mu \mathrm{m}$ ) arising from a smooth stipe (width around 2-4 $\mu \mathrm{m}$ ). The ability of the isolate MF18_10 to grow on various media simulating the low water activity (Table 1) as well as on conventional malt extract agar indicated the xerotolerance of this fungus with the potential ability to grow and cause damage on the walls under conditions of low humidity in the $\mathrm{Ca}$ thedral.

BLAST nucleotide analysis carried out, using the ITS primary structure of studied $P$. chrysogenum MF18_10 (MK367422, 585 bp), revealed more than 12,000 sequences of rRNA clusters of fungi with varying homology to the reference one.

The molecular size of the ITS sequences homologous to the reference MK367422 varied from 585 bp. (e.g. JX136719 for $P$. chrysogenum XF5) to 1258 bp (e.g. LT558875 for $P$. chrysogenum DI16-53). BLASTN analysis showed 898 hits of the fungal rRNA clusters for $P$. chrysogenum spe- cies with identities to the primary reference varying from $100 \%$ to $81 \%$ and query cover ranging from $100 \%$ to $9 \%$. It should be noted, that some of the sequences have smaller molecular sizes than the reference ITS sequence MK367422. For example, the ITS sequence of $P$. chrysogenum SDSP (MG214658, 543 bp) includes ITS1, 5.8S rRNA and ITS2; whereas ITS sequence NCPF2881 (241 bp) consisted of only ITS1 and 5.8S rRNA; as well as the $P$. chrysogenum DPL-8 ITS (MF000932, 256 bp) contained only 5.8S rRNA and ITS2. Our study was focused only on the database ITS sequences with the query cover $100 \%$ compared to our reference. The ITS of 105 strains of the genus Penicillium and uncultured penicillia were found to be fully identical (100\%) to the MK367422 primary structure with $100 \%$ query cover and e value $=0.0$ (Fig. 1B). Most of them (74\%) were the ITS sequences of $P$. chrysogenum strains, including the fragment of the rRNA cluster of the type strain $P$. chrysogenum CBS 306.48 (NR_077145, 585 bp) (Fig. 2).

As known, the $P$. chrysogenum strains are the most common among the penicillia and are found on all continents. The strains, chosen through ITS BLAST analysis for their $100 \%$ identity to the reference one, were reported to be isolated from the samples collected in Europe (Ukraine, Bulgaria, Slovakia, Italy), North America (Canada, USA), South America (Brazil, Costa Rica), Asia (Russia, China, Japan), and North Africa. A number of P. chrysogenum strains (DTO 103E7, DTO 149C1, DTO 149C2, DTO 149C3) were isolated from soil samples taken in the Dry Valley of Antarctica. Considered representatives of $P$. chrysogenum species were found both in the outdoor environment (strawberry fields, groves of olive trees, cave walls), and in the indoors (various buildings, houses, graves, museums). These fungi are also common on plants (grapes, hyssop, olive trees, kiwi, barley), processed foods (cheese, ham, bread products, yoghurt), and also reported in cosmetics and on documents. Some representatives of P. chrysogenum species might also be pathogenic for humans, insects and plants as well as the contaminant microorganisms of laboratory cultures or production processes.

Table 1 . The colony diameter (mm) after P. chrysogenum MF18_10 growth on different agar media for 14 days at $25^{\circ} \mathrm{C}$

\begin{tabular}{|c|c|c|c|c|c|}
\hline MEA & MEA+10\% NaCl & PDA+15 \% NaCl & MY40S & CY20S & C70S \\
\hline $25-35$ & $28-35$ & $1-4$ & $19-27$ & $21-30$ & $15-21$ \\
\hline
\end{tabular}



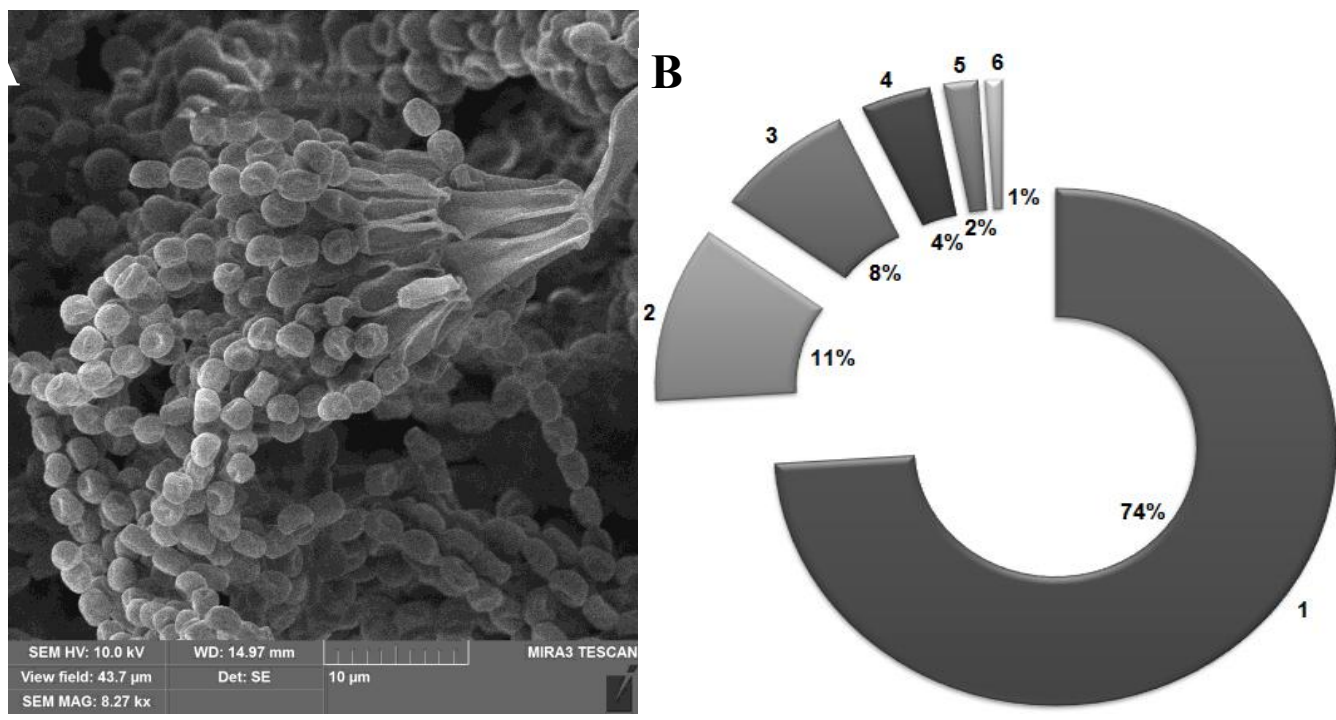

Fig. 1. (A) SEM of the conidiophore of Penicillium sp. isolate MF18_10; (B) ITS sequences for 105 representatives of Penicillium spp. with the primary structure identical (100\%) to the isolate MF18_10: (1) P. chrysogenum, (2) P. allii-sativi, (3) Penicillium sp., (4) uncultured Penicillium fungi, (5) P. tardochrysogenum, (6) P. desertorum.

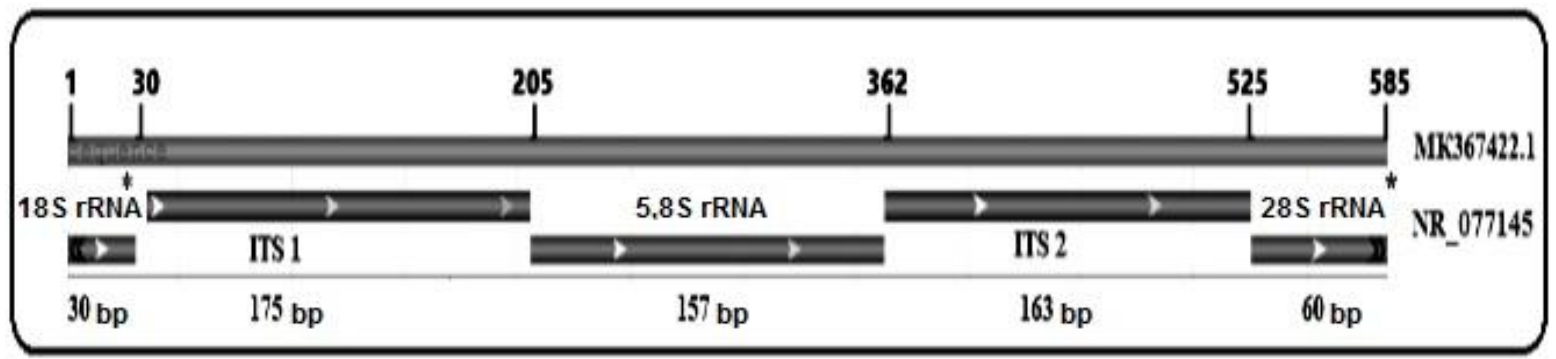

Fig. 2. ITS structure of $P$. chrysogenum strain MF18_10 (MK367422) compared to the type strain $P$. chrysogenum CBS 306.48 (NR_077145). * - a partial sequence of rRNA genes.

Considering that the $P$. chrysogenum MF18_10 strain was isolated by us from the medieval wall paintings, we were interested in other originated from similar environments representatives of this species with identical (100\%) or highly homologous (99.9-96\%) primary ITS structure. Among data for fully identical to the reference ITS sequences, several strains of this species were isolated from the surface of the art works: P. chrysogenum FX5 (JX136719) and P. chrysogenum FX43 (KJ780803) from wall paintings; P. chrysogenum DTO 149 B5 (JX997027) from oil painting; $P$. chrysogenum H09-022 (KC009774.1) and $P$. chrysogenum WL5-2B (MF422150) from $19^{\text {th }}$ century collection items. Many of these strains were isolated from both walls and air samples taken in various parts of buildings, museums, tombs, industrial premises, and termitaries (Tables 2, 3) [9, 13, 14].

As a result of verified alignments, there were found ITS fragments of $93 P$. chrysogenum strains with high homology values (identities $=99.8 \%$ $96 \%$; e value $=0.0$; query cover $=100 \%$ ). We determined the mismatches and gaps localization in their ITS structures (Fig. 3). It was found that $17.1 \%$ of the $P$. chrysogenum strains contained the inserts of 1 or 2 nucleotide residues corresponding to 6 nucleotide residues of the reference ITS. In addition, in $77 \%$ of the strains, the thymine residue corresponds to the $362^{\text {nd }}$ cytosine residue of the reference ITS. In $14.5 \%$ of the strains, there are substitutions and gaps corresponding to $513^{\text {rd }}$ and $516^{\text {th }}$ residues. Inserts of 1 or 2 residues corresponding to the $577^{\text {th }}$ nucleotide residue of the reference ITS were found in $3.1 \%$ of the strains (Fig. 3). Thus, both the regions of the spacers (ITS1 and ITS2) and the rRNA genes (18S rRNA and 28S rRNA) manifested the differences (substitutions and breaks) in the rRNA operons primary structure for the $P$. chrysogenum strains. 
Table 2. Information about selected $P$. chrysogenum strains with ITS primary structures completely identical* to the isolated from St. Sophia's Cathedral P. chrysogenum MF18_10 (MK367422.1)

\begin{tabular}{|c|c|c|}
\hline Strains & $\begin{array}{c}\text { GenBank } \\
\text { Accession N }\end{array}$ & Isolation sources \\
\hline CBS 306.48 & NR_077145 & TYPE material, CBS collection, USA \\
\hline FRR 807 & AY373902 & TYPE material, USA \\
\hline JCM 22826 & AB479305 & the stone chambers in the Takamatsuzuka and Kitora Tumuli, \\
Japan
\end{tabular}

Notes: $*$ - identity grades of all strains were $-\overline{\text { Identities }}=100 \%, \mathrm{E}$ value $=0.0$, Query cover $=100 \%$.

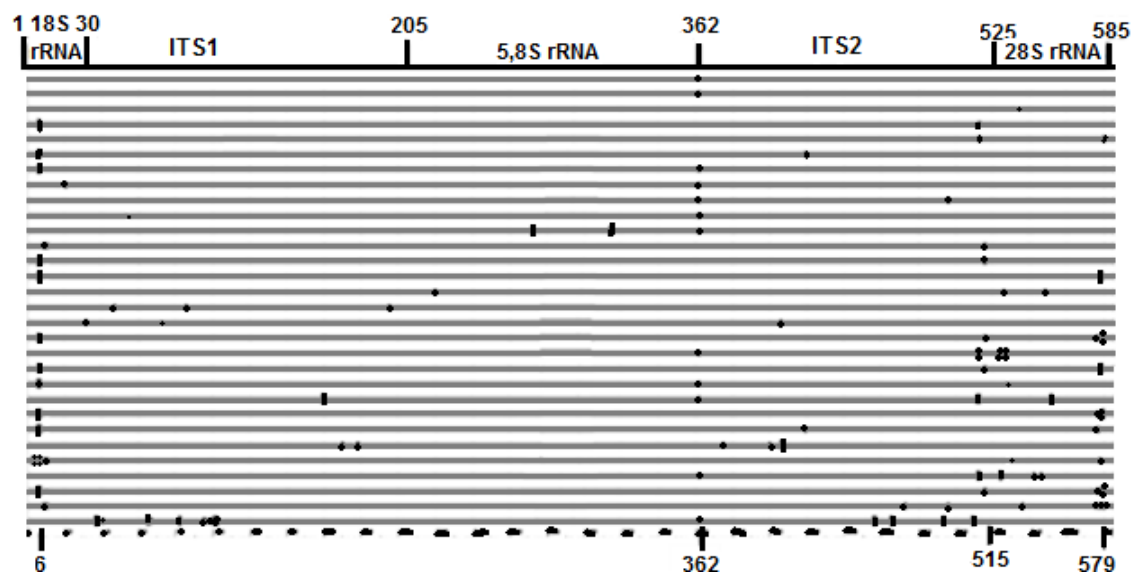

Fig. 3. The localization of nucleotide bases mismatches in the ITS region of the strain P. chrysogenum MF18_10 (MK367422) and the selected P. chrysogenum strains from GenBank.

It was found that nucleotide transitions take place more often (12 substitutions) than transversions (4 substitutions) (Table 3). The similar substitutions may happen for the strains originated from the diverse sources. There are the same substitutions in the nucleotide sequences of the ITS of P. chrysogenum strains JX997051 and JX996998 (transitions of 205 n.); EU833212 and KJ780802 (transitions of $259 \mathrm{n}$.); JX997044 and JX997045 (transitions of $514 \mathrm{n}$.). Some strains originated from geographically remote areas (e.g. EU833212 from Mexico and KJ780802 from China) as well as from the same locations (e.g. sequences of $P$. chrysogenum strains isolated from the surface of murals in $\mathrm{Xu}$ Xian Xiu's tomb, China KJ780802, JX136726, JX136729). Also, it was observed a certain trend in the substitutions in the ITS sequences originated from the Mogao Grottoes cave, China (HQ380775 and HQ380757): the ITS of these strains had the largest number of substitutions (Table 3 ). 
Table 3. The differences in the primary structures of ITS region of selected $P$. chrysogenum strains (with identity $99.1-99.8 \%)^{\mathbf{I g}}$ in comparison to the reference ITS of isolated from St. Sophia's Cathedral P. chrysogenum MF18_10 (MK367422)

\begin{tabular}{|c|c|c|c|}
\hline Strains & $\begin{array}{c}\text { GenBank } \\
\text { Accession } \mathrm{N}\end{array}$ & $\begin{array}{c}\text { Identity }(\%) \text { and mismatches in ITS } \\
\text { primary structures } \\
\text { (substitutions } \mathbf{R}: \mathbf{X} \rightarrow \mathbf{Y})\end{array}$ & Isolation sources \\
\hline DTO 87I2 & JX997051 & $\mathrm{I}=99.8 \% \mathbf{R}: \mathrm{T} \rightarrow \mathrm{C}(204 \mathrm{n} .)^{*} \mathbf{T s}$ & archive, Netherlands \\
\hline 102B4 & JX996998 & $\mathrm{I}=99.8 \% \quad$ R: $\mathrm{T} \rightarrow \mathrm{C}(204$ n.) $\mathbf{T s}$ & house dust, USA \\
\hline DTO 102B7 & JX997001 & $\mathrm{I}=99.8 \% \mathbf{R}: \mathrm{A} \rightarrow \mathrm{G}(514$ n.) Ts & house dust, USA \\
\hline DTO 64E8 & JX997044 & $\mathrm{I}=99.8 \%$ R: $A \rightarrow G(514$ n.) Ts & $\begin{array}{l}\text { industrial premises (vaccine } \\
\text { production), Netherlands }\end{array}$ \\
\hline DTO 68B8 & JX997045 & $\mathrm{I}=99.8 \% \mathbf{R :} \mathrm{A} \rightarrow \mathrm{G}(514$ n.) Ts & industrial premises, Germany \\
\hline P11.7 & EU833212 & $\mathrm{I}=99.8 \% \mathbf{R}: \mathrm{A} \rightarrow \mathrm{G}(259$ n. $)$ Ts & Los Riscos cave soil, Mexico \\
\hline XF42 & KJ780802 & $\mathrm{I}=99.8 \% \mathbf{R}: \mathrm{A} \rightarrow \mathrm{G}(259 \mathrm{n}.) \mathrm{Ts}$ & \multirow{2}{*}{$\begin{array}{l}\text { Xu Xian Xiu's tomb murals, } \\
\text { China }\end{array}$} \\
\hline XF12 & JX136726 & $\mathrm{I}=99,8 \% \mathbf{R :} \mathrm{T} \rightarrow \mathrm{G}(69$ n. $) \quad \mathbf{T v}$ & \\
\hline F23 & HQ380775 & 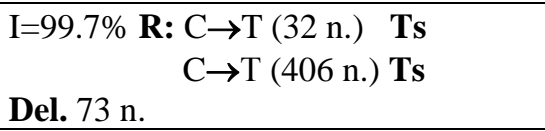 & Mogao Grottoes cave, China \\
\hline XF15 & JX136729 & $\begin{aligned} \mathrm{I}=99.5 \% \mathbf{R}: & \mathrm{A} \rightarrow \mathrm{C}(21 \mathrm{n.}) \mathrm{Tv} \\
\mathrm{C} \rightarrow \mathrm{T}(362 \text { n.) } & \mathbf{T s}\end{aligned}$ & $\begin{array}{l}\text { Xu Xian Xiu's tomb murals, } \\
\text { China }\end{array}$ \\
\hline $\mathrm{F} 2$ & HQ380757 & 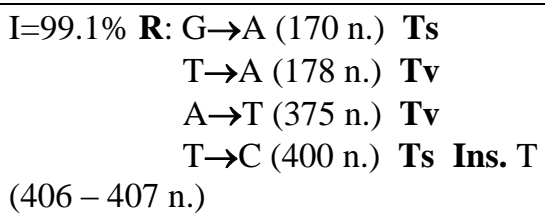 & Mogao Grottoes cave, China \\
\hline
\end{tabular}

Notes: ${ }^{\mathbf{I g}}$ - Identity grades of selected strains: Query cover $=100 \%$, E value $=0.0 ; \mathbf{R}-$ Amino acid replacement, $\mathbf{X}-$ the nucleotide residue in reference ITS MK367422, Y - the nucleotide residue in the homologous ITS fragments, Ins - insertion, Del - deletion, $\mathbf{T v}$ - transversion of nucleotide residue, $\mathbf{T s}$ - transition of nucleotide residue. ${ }^{*}$ - localization of substitutions, deletions and insertions.

\section{Conclusions}

Thus, on the basis of the phenotypical characteristics of the isolate MF18_10 from the deteriorated walls with medieval murals in St. Sophia's Cathedral in Kyiv, its affiliation to the genus Penicillium was established. Its taxonomic position as $P$. chrysogenum strain MF18_10 was confirmed by computerized analysis of the ITS-fragment nucleotide sequence (MK367422), showing its complete identity to the ITS-fragments of type strains NR_077145 and AY373902, and also other 78 P. chrysogenum strains in GenBank database. Our study showed that the isolated strain MF18_10 be- longs to the common for indoor environments, dust, aerosols penicillia, which are also often isolated from historical-cultural artifacts. This $P$. chrysogenum isolate was found to be xerotolerant and might contribute to the destruction of the ancient wall paintings. However, considering that the deterioration of the valuable heritage objects is often caused by xerophilic fungi which are very difficult to cultivate under laboratory conditions, there will be needed further multidisciplinary studies on mycobiota of the dark stains on the St. Sophia's Cathedral murals.

\section{References}

1. Chen A., Hubka V., Frisvad J., Visagie C., Houbraken J., Meijer M. et al. Polyphasic taxonomy of Aspergillus section Aspergillus (formerly Eurotium), and its occurrence in indoor environments and food. Studies in Mycology. 2017. Vol. 88. P. 37135. doi: 10.1016/j.simyco.2017.07.001.

2. $\quad$ Liu Z., Zhang Y., Zhang F., Hu C., Liu G., Pan J. Microbial Community Analyses of the Deteriorated Storeroom Objects in the Tianjin Museum Using Culture-Independent and Culture-Dependent Approaches. Frontiers in Microbiology. 2018. Vol. 9. P. 802. doi: 10.3389/fmicb.2018.00802.

3. Unković N., Ljaljević Grbić M., Subakov-Simić G., Stupar M., Vukojević J., Jelikić A. et al. Biodeteriogenic and toxigenic agents on 17th century mural paintings and façade of the old church of the Holy Ascension (Veliki Krčimir, Serbia). Indoor and Built Environment. 2015. Vol. 25 (5). P. 826-837. doi: 10.1177/1420326X15587178. 
4. Sklenář F., Jurjević Ž., Zalar P., Frisvad J. Visagie C., Kolařík M. et al. Phylogeny of xerophilic aspergilli (subgenus Aspergillus) and taxonomic revision of section Restricti. Studies in Mycology. 2017. Vol. 88. P. 161-236. doi: 10.1016/j.simyco.2017.09.002.

5. Tanney J., Visagie C., Yilmaz N., Seifert K. Aspergillus subgenus Polypaecilum from the built environment. Studies in Mycology. 2017. Vol. 88. P. 237-267. doi: 10.1016/j.simyco.2017.11.001.

6. Schoch C., Seifert K., Huhndorf S., Robert V., Spouge J., Levesque C. et al. Nuclear ribosomal internal transcribed spacer (ITS) region as a universal DNA barcode marker for Fungi. Proceedings of the National Academy of Sciences. 2012. Vol. 109 (16). P. 6241-6246. doi: 10.1073/pnas.1117018109.

7. Houbraken J., Frisvad J., Seifert K., Overy D. Tuthill D., Valdez J. et al. New penicillin-producing Penicillium species and an overview of section Chrysogena. Persoonia - Molecular Phylogeny and Evolution of Fungi. 2012. Vol. 29 (1). P. 78-100. doi: 10.3767/003158512X660571

8. Mueller G.M., Bills G.F., Foster M.S. Biodiversity of fungi. Inventory and monitoring methods. Burlington (USA): Elsevier Academic Press, 2006. 777 p.

9. Koval E.Z., Rudenko A.V., Goncharuk V.V., Voloshchuk N.M. Penicillia in the environment. Kyiv: Naukova Dumka, 2014. Part 1, 436 p., Part 2. 386 p. [in Ukrainian] / Коваль Е.3., Руденко А.В., Гончарук В.В., Волощук Н.М. Пеніцилії в навкольшньому середовищі. К.: Наукова думка, 2014. Ч. 1. 436 с., Ч. 2. 386 с.

10. Polishchuk L.V., Tkachenko K.S. Fomina M.A. Characteristics of ITS-fragment of rDNA of Rhodotorula mucilaginosa isolated from gastrointestinal tract of centenarian. Factors in Experimental Evolution of Organisms. 2017. Vol. 21. P. $284-287$.

11. Fomina M.A., Polishchuk L.V., Tkachenko K.S., Hong J.W., Zelena L.B., Ianieva O.D., Pidgorskyi V.S. Complex identification of red yeast isolate from gastrointestinal tract of Hucul long-liver (Carpathians, Ukraine). Mikrobiolohichnyi zhurnal. 2016. Vol. 78 (5). P. 2-11.

12. Hong J., Fomina M., Gadd G. F-RISA fungal clones as potential bioindicators of organic and metal contamination in soil. Journal of Applied Microbiology. 2010. Vol. 109 (2). P. 415-430. doi: 10.1111/j.1365-2672.2009.04665.x.

13. An K. Kiyuna T., Kigawa R., Sano C., Miura S, Sugiyama J. The identity of Penicillium sp. 1, a major contaminant of the stone chambers in the Takamatsuzuka and Kitora Tumuli in Japan, is Penicillium paneum. Antonie van Leeuwenhoek. 2009. Vol. 96 (4). P. 579-592. doi: 10.1007/s10482-009-9373-0.

14. Coronado-Ruiz C., Avendaño R., Escudero-Leyva E., Conejo-Barboza G., Chaverri P., Chavarría M. Two new cellulolytic fungal species isolated from a 19th-century art collection. Scientific Reports. 2018. Vol. 8 (1). P. 7492. doi: 10.1038/s41598018-24934-7.

\section{ЛУЦЕНКО В. О. ${ }^{1}$, ПОЛІЩУК Л. В. ${ }^{1}$, ХОНГ Дж. ${ }^{2}$, ФОМІНА М. О. ${ }^{1}$}

${ }^{1}$ Інститут мікробіології та вірусології ім. Д.К. Заболотного НАН Украӥни, Україна, 03143, м. Київ, вул. Академіка Заболотного, 154, e-mail: M.Fomina@ukr.net

${ }^{2}$ Корейський Інститут Морського Біорізноманіття,

Південна Корея, 33662, Чунхчеонхем-до

\section{КСЕРОТОЛЕРАНТНИЙ ШТАМ РЕNICILLIUM CHRYSOGENUM MF18_10, IЗОЛЬОВАНИЙ I3 ПОШКОДЖЕНИХ СТІН СОФІЇВСЬКОГО СОБОРУ, КИЇВ}

Mema. Метою роботи було визначення таксономічного положення штаму гриба MF18_10, ізольованого із пошкоджених стін з середньовічними фресками Софійського собору (Київ, Україна). Методи. Гриб було виділено в чисту культуру на селективному для ксерофільних грибів середовищі (агар Чапека з 70 \% сахарози). Для макрота мікроморфологічної характеристики застосовували світлову та скануючу електронну мікроскопію. Молекулярно-біологічну ідентифікацію проводили з використанням нуклеотидної послідовності фрагменту ITS. Peзультати. На основі фенотипової характеристики грибного ізоляту MF18_10 було встановлено його приналежність до роду Penicillium. Аналіз ITS виявив, що ізолят належить до виду P. chrysogenum, демонструючи його $100 \%$ ідентичність 3 іншими 78 штамами P. chrysogenum в базі даних GenBank, включаючи типові штами NR_077145 і AY373902, а також поділяючи характерні відмінності в заміщеннях, делеціях і вставках в межах цієї групи. Висновки. Ізольований ксеротолерантний гриб було ідентифіковано як P. chrysogenum, типовий представник внутрішніх приміщень і пилу, а також поширений в мікобіоті пошкоджених історично-культурних артефактів вид. Відмінності в проаналізованих первинних структурах ITS P. chrysogenum не корелювали 3 джерелом виділення.

Ключові слова: Penicillium chrysogenum, ксеротолерантні гриби, ITS, скануюча електронна мікроскопія. 